\title{
Structural relationships between self-regulated learning, teachers' credibility, information and communications technology literacy and academic performance in blended learning
}

\author{
Liang Yu \\ Faculty of Education, Southwest University, P. R. China \\ Shijian Chen \\ Faculty of Education, Southwest University, P. R. China
}

Mimi Recker

Emma Eccles Jones College of Education and Human Services, Utah State University, USA

\begin{abstract}
This study investigated the structural relationships between self-regulated learning, teachers' credibility, information and communications technology (ICT) literacy and academic performance in blended learning. The study sample comprised of 449 undergraduates who completed blended courses within the past 3 years and consisted of 53\% males $(N=238)$ and $47 \%$ females $(N=211)$. Participants anonymously completed a 41-item questionnaire examining their self-regulated learning, perceptions of their teachers' credibility, ICT literacy, academic performance and demographic background. Path analyses indicated that the relationship between subscales of teacher credibility (caring and trustworthiness) significantly related to academic performance except for competence. In addition, caring positively predicted trustworthiness, and ICT literacy predicted self-regulated learning. Selfregulated learning positively related to caring, trustworthiness and academic performance. The findings also highlighted that both caring and trustworthiness mediated the impact of self-regulated learning on academic performance.
\end{abstract}

Implications for practice or policy:

- College teachers can improve students' academic performance by enhancing students' perception about their caring and trustworthiness.

- College teachers may need to give more opportunity for students to self-regulate their learning.

- College teachers can express care towards their students to improve individual relationships as well as affect the broader climate and then gain the students' trust.

- College governors may consider making policies to guide teachers to attach more importance to their teaching.

Keywords: ICT literacy, self-regulated learning (SRL), teachers' credibility, academic performance, path analysis

\section{Introduction}

As a consequence of rapid advancement in information and communication technologies, innovative instructional delivery and learning solutions have emerged to stimulate and enhance teaching and learning processes in academic settings. One increasingly common example of innovative, technology-supported instructional approach is blended learning. Blended learning is the deliberate combination of classroom face-to-face learning with online learning (Garrison \& Kanuka, 2004). With this combination, students have access to online resources and contact with teachers to get support and advice, as well as attend faceto-face instruction (Moskal et al., 2013; Y. Zhu et al., 2016). In this way, blended learning can offer significant advantages in supporting higher levels of learning through critical discourse and reflective thinking (Garrison \& Kanuka, 2004; Shea \& Bidjerano, 2010). These advantages include a self-paced learning experience, better communication, round-the-clock access to learning resources and the tracking of participants' skill and performance development. 
Numerous studies have examined the relationships between individual and instructional factors and academic performance in blended learning contexts. Some research has addressed several factors affecting academic performance: self-regulated learning (SRL) (Shea \& Bidjerano, 2010; Zimmerman, 2008), information and communications technology (ICT) literacy (Tang \& Chaw, 2016), assessment approaches (Awang \& Zakaria, 2013; Jia et al., 2012) and training materials used (Akkoyunlu \& Yilmaz-Soylu, 2008). However, little research on blended learning has focused on the role of the teacher (Ibrahim \& Nat, 2019). Teachers are the gatekeepers to learning, who influence the nature and quality of students' learning through the selection and design of learning experiences (Jeffrey et al., 2014). Teachers scaffold students to achieve the task within the students' reach during instruction (Bruner, 2009).

In particular, prior studies of face-to-face classroom teaching have identified an important aspect in teachers - their credibility. This is defined as a combination of competence, trustworthiness and caring towards students (Finn et al., 2009; Teven \& McCroskey, 1997). Credibility, however, has been much less examined in blended learning settings. Therefore, the purpose of the present study was to investigate the structural relationship between predictors of success in blended learning (SRL, ICT literacy), teachers' credibility and academic performance in blended learning contexts.

\section{Literature review}

\section{SRL}

SRL refers to learning that results from students' self-generated thoughts and behaviours that are systematically oriented towards the attainment of their learning goals. Generally, SRL has three identifiable phrases: (a) preparatory, which includes task analysis, strategy selection and goal-setting and planning; (b) performance, in which the actual task is done while monitoring and controlling the progress of performance; and (c) appraisal, in which the student reflects on and reacts for future performances (Puustinen \& Pulkkinen, 2001).Typically, self-regulated learners utilise several cognitive and metacognitive strategies to achieve goals and manage time and effort to optimise their performance (You \& Kang, 2014). Once concentrated on a given task, they explore the task's conditions for completion and then set their goals as well as monitor their own general learning process and arrive at SRL (Joo et al., 2014). SRL is a selfdirective process by which learners seek to monitor, regulate and control their cognition, motivation and behaviour in order to achieve their learning goals (Pintrich, 2000; Schunk \& Zimmerman, 1994).

Researchers have developed several SRL models with different constructs (Boekaerts \& Corno, 2005; Butler \& Winne, 1995; Efklides, 2011; Hadwin et al., 2011; Pintrich, 2000; Zimmerman, 2000). Although each model has different theoretical perspectives, they all feature common characteristics - that is (a) a cyclical process, (b) comprised of cognition, metacognition, motivation and emotion and (c) a set of skills that can be developed and learned (Panadero \& Alonso-Tapia, 2014). Both Pintrich's and Zimmerman's models stand out as distinct approaches to describe the same process. Pintrich's model focuses on different kinds of SRL strategies and defines SRL as "an active, constructive process whereby learners set goals for their learning and then attempt to monitor, regulate and control their cognition, intentions and behaviour, guided and constrained by their goals and the contextual features of the environment" (Pintrich, 2000, p. 453). By contrast, Zimmerman's model divides SRL into personal, behavioural and environmental processes and defined SRL as "self-generated thoughts, feelings, and actions that are planned and cyclically adapted to the attainment of personal goals" (Zimmerman, 2000, p 14).

The current study is theoretically situated as a combination of Pintrich's (2000) and Zimmerman's (2000) models as they focus on the interplay between strategies and processes. Therefore, SRL is composed of goal orientation, self-efficacy, cognitive strategies, metacognitive strategies and self-management. Goal orientation refers to students' disposition towards developing or validating their ability in achievement settings (Vandewalle, 1997). Self-efficacy describes students' perceived beliefs about their competences or abilities to successfully accomplish a specific task (Bandura,1993). Cognitive strategies involve students' use of basic strategies in the acquisition, storage and retrieval of information (Pintrich, 2000). Metacognitive strategies concern students' use of strategies to plan, monitor and regulate their learning process to accomplish a goal (Pintrich et al., 1993). Self-management encompasses students' utilisation of strategies to manage the learning environment and external resources (Y. Zhu et al., 2016). 
Many researchers have developed research instruments under the umbrellas of specific SRL models, which have been described in the educational literature (for a recent literature review see Panadero, 2017). Moreover, several SRL instruments have been devised according to integrated views of different SRL models (Barnard et al., 2009; Kuo et al., 2014; Wang et al., 2013; Z. Zhu et al., 2005). The instrument of SRL in the present study follows the combination of Pintrich's model and Zimmerman's model and has five sub-scales: goal orientation, self-efficacy, cognitive strategies, metacognitive strategies and selfmanagement.

The relationship between SRL and academic performance has been theorised under the social cognitive view that SRL involves three classes of performance-related subprocesses: self-observation, self-judgment and self-reaction (Bandura, 1986). They are assumed to work in conjunction with each other. Selfobservation refers to students' deliberate attention to aspects of their behaviours; self-judgment means students compare their performance with a standard or goal; self-reaction is described as students' response to their performance (Zimmerman, 1989). Moreover, this view holds that students can be trained to become self-regulated learners by utilising and acquiring SRL strategies. These strategies may exert an effect on learning outcomes by assisting students to gain and retain knowledge in a structured and methodological way (Broadbent \& Poon, 2015).

Previous studies have shown that SRL has been positively associated with academic achievement in online learning (Barnark-Brak et al., 2010; Puzziferro, 2008), blended learning (Y. Zhu et al., 2016), as well as in face-to-face learning contexts (Pintrich, 2004; Zimmerman, 1989, 2008).

\section{Teacher credibility}

Tracing back to Aristotle, credibility has long been assumed as an important and powerful resource in persuasive speaking (Cooper, 1932). In particular, a speaker's persuasion is more prone to occur on the condition that the speaker is identified as a credible one (Tormala et al., 2006). Cooper (1932) pointed out that humans are more likely to believe individuals identified to be credible. Likewise, teacher credibility refers to the extent to which a teacher is considered to be believable and trusted by students (McCroskey, 1998). A credible teacher is able to teach complicated subject content in a way that students can easily grasp as well as reply to students' questions efficiently and clear up their misconceptions (Pogue \& AhYun, 2006).

Teacher credibility is viewed as a combination of competence and character and appears to be multidimensional (McCroskey \& Young, 1981). Based on this, Thweatt and McCroskey (1998) defined teacher credibility across four dimensions: trust, competence, dynamism and immediacy. Trust refers to the trustworthiness of the person. Competence refers to content knowledge that the teacher possesses. Dynamism is a measure of the enthusiasm the teacher displays for the subject being taught and immediacy is the level of responsiveness to students, including nonverbal signals such as eye contact and proximity. The model developed by McCroskey (1992) stands out in the literature as a distinct approach, which offers three basic dimensions for teacher credibility: competence, trustworthiness and caring. Competence refers to sufficiency of knowledge and skills in a particular subject. If a teacher is to be perceived as competent, they not only possess strong subject matter knowledge but also good teaching skills to be able to explain complex content well, manage a classroom effectively and communicate with students efficiently (Teven \& Hanson, 2004). Trustworthiness is accounted for by the degree to which a teacher is perceived as honest by students (McCroskey, 1998). A trustworthy teacher gives immediate feedback to students' requests, offers reasonable explanations for giving marks and treats students fairly. Finally, perceived caring refers to the students' perception of their teachers in terms of how much they recognise their values, well-being and interests (McCroskey \& Teven, 1999). Teachers must be able to communicate in such a manner that students will perceive that they care about them (Teven \& Hanson, 2004).

Following McCroskey's (1992) model, researchers have developed several measurement scales for teacher credibility (Hutchens \& Hayes, 2014; Ledbetter \& Finn, 2016; McCroskey \& Teven, 1999; Q. Zhang et al., 2011; Richmond et al., 2006; Teven \& McCroskey, 1997). The measurement scale designed by McCroskey and Teven (1999) remains most popular in the domain of communication and learning. The present study followed McCroskey's model (1992) and uses McCroskey and Teven's (1999) scale because it has a reliable internal consistency tested by other studies and is widely cited in the literature (Banfield et al., 2006; Mazer et al., 2009; Westerman et al., 2012). 
Many studies have shown that students who perceived their teachers as credible were more prone to report that they learned more and improved their learning outcomes (Finn et al., 2009; Gray et al., 2011; McCroskey \& Teven, 1999; Pogue \& AhYun, 2006; Teven \& Hanson, 2004). However, there has been little research examining the influence of teacher credibility on learning outcomes in online or blended learning.

\section{ICT literacy}

Several concepts or terms have similar meaning to ICT literacy, such as computer literacy (Özsevgeç, 2011), digital literacy (Bawden, 2008), computer and information literacy (Rohatgi et al., 2016) and information literacy (Webber \& Johnston, 2000). All of them have two common features: one is that a term concerning ICT is related to having the capability to use and benefit from using it; the other is that these concepts describe achievements with ICT, which can be readily adapted and transferred to new contexts (Fraillon et al., 2013).

The present study applied the concepts of ICT literacy defined as "the interest, attitude and ability of individuals to appropriately use digital technology and communication tools to access, manage, integrate and evaluate information, construct new knowledge and communicate with others in order to participate effectively in society" (Lennon et al., 2003, p. 8). The definition highlights ICT literacy as the capability of a person to use digital technologies, communication tools and/or computer networks to solve problems in all learning areas and their life in order to function in an information society.

There is a generally accepted notion shared among instructors that a higher level of ICT literacy can lead to enhanced student academic performance and increased employment opportunities (Jaderstrom, 1995; Ye, 2000). Indeed, recent research has identified the positive correlation between ICT literacy and academic performance for college students (Godbey, 2018; Squibb \& Mikkelsen, 2016).

\section{Research questions and hypotheses}

Social cognitive theory is a theory of psychological functioning that emphasises learning from the social environment. Bandura (1977) highlighted two influences on behaviour: (a) modelling and thus vicarious learning of behaviour and (b) one's personal beliefs about the ability to perform specific behaviours. Social cognitive theory includes an emphasis on modelling and guidance as key supports for the acquisition of SRL (Zimmerman, 2000). The teacher is first and foremost the model by which students learn SRL strategies in each of the three phases of SRL (forethought, performance control, self-reflection) (Zuckerman, 1994). Importantly, through teacher modelling, feedback and reinforcement, students learn that the results of these SRL strategies need to be accurate, view their teachers as credible sources and want to be valued by them. One interesting omission in research on the social cognitive approach to SRL seems directly related to teacher credibility (Evertson \& Weinstein, 2006).

Based on the literature reviewed, previous studies have addressed the relationship between SRL, ICT literacy, perceptions of teachers' credibility and academic performance, but little research has examined these variables simultaneously, as well as in blended learning settings. Therefore, the following two research questions guided the design of this research:

- Research question 1: What are the relationships between SRL, perceptions of teachers' credibility, ICT literacy and academic performance in blended learning?

- Research question 2: Do perceptions of teachers' credibility mediate effects between SRL and academic performance?

Addressing these questions, we proposed a conceptual model based on social cognitive theory as shown in Figure 1, which hypothesised relationships between SRL, perceptions of teachers' credibility (competence, trustworthiness and caring), ICT literacy and academic performance. 


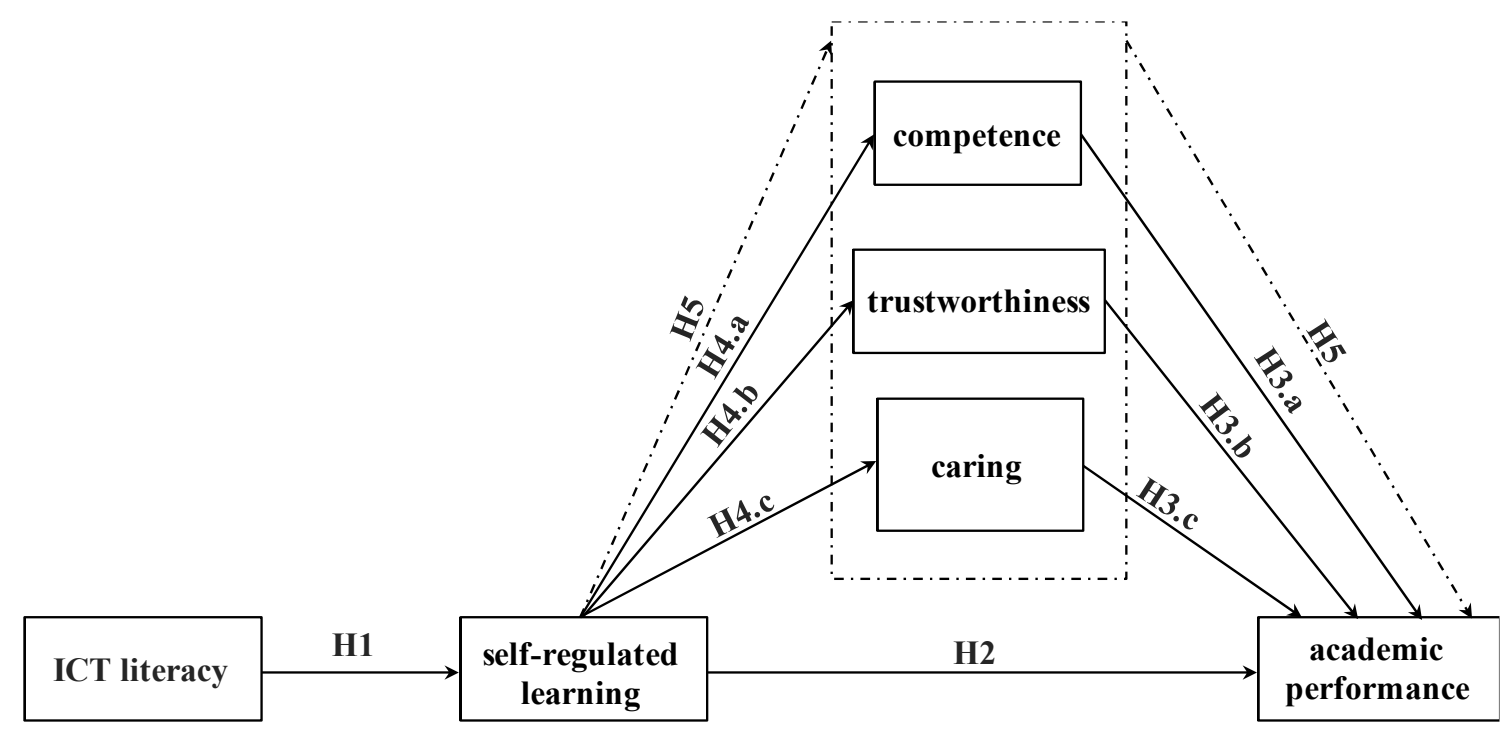

Figure 1. The initial model

\section{ICT literacy and SRL}

Blended learners should be self-regulated, have the capability of independent study and control over their learning because students and teachers are not present simultaneously in the same setting at most times. Moreover, they should be ICT literate and be able to use information resources presented via distributed learning technologies. Many studies have shown that both ICT literacy (Godbey, 2018; Squibb \& Mikkelsen, 2016) and SRL (Barnark-Brak et al., 2010; Puzziferro, 2008; Y. Zhu et al., 2016) are significantly related to academic performance. Other studies revealed that there was a positive correlation between ICT literacy and SRL (Greene et al., 2014; Kiliç-Çakmak, 2010; M. S. Yang \& Kim, 2014). Therefore, we posited a positive relation between ICT literacy and SRL in blended learning:

H1. ICT literacy positively correlates with SRL.

\section{SRL and academic performance}

Self-regulated students can use SRL strategies to acquire more knowledge and attain higher academic performance. Zimmerman and Schunk (2012) examined the relationship between SRL and academic performance and found that students with higher SRL skills have higher academic achievement in face-toface learning settings, which is consistent with other research in online learning (Barnark-Brak et al., 2010; Puzziferro, 2008) and blended learning (Y. Zhu et al., 2016). Accordingly, we formulated the second hypothesis:

H2. SRL positively correlates with academic performance.

Teachers' credibility and academic performance

A credible teacher is knowledgeable about a given subject matter, concerned about students' welfare and respected by students (McCroskey, 1998). Gray et al. (2011) demonstrated that a teacher who is perceived by their students as a credible source tends to build better relationship with students and to enhance their learning outcomes. Other studies also indicated that there was a positive relation between perceptions of teachers' credibility and academic performance in traditional course (Finn et al., 2009; Pogue \& AhYun, 2006; Teven \& Hanson, 2004). We expected a positive relation between teachers' credibility and academic performance in the same vein for blended learning and put forward the following hypotheses.

H3. Teachers' credibility positively correlates with academic performance.

H3a. Competence positively correlates with academic performance.

H3b. Trustworthiness positively correlates with academic performance.

H3c. Caring positively correlates with academic performance. 
SRL and perceptions of teachers' credibility

Self-regulated learners have the potential to achieve their learning goals by controlling their learning situations, thus achieving higher academic performance. Many studies have indicated that students who perceived their teachers as credible were more prone to report that they got better grades. (Gray et al., 2011; Finn et al., 2009; Teven \& Hanson, 2004). Self-regulated learners tend to acquire higher marks and then attract more attention from their teachers, which helps to build a good relationship between students and teachers and increases students' perceptions of the teachers' credibility (Y. Zhang \& Rong, 2013). Therefore, we put forward the following hypotheses:

H4. SRL positively correlates to perceptions of teachers' credibility.

H4a. SRL positively correlates to competence.

H4b. SRL positively correlates to trustworthiness.

H4c. SRL positively correlates to caring.

The mediating effects of perceptions of teachers' credibility

Taking hypotheses 3 and 4 together, we proposed an indirect effect of SRL on academic performance via perceptions of teachers' credibility. Self-regulated students cyclically used a deliberate, judgemental and adaptive process to adjust their strategies for approaching learning tasks, interact effectively with their surrounding environment, showed higher thinking skills in solving problems, which attracted teachers' attention and caring, arousing them to perceive their teachers as credible, which then improved their academic performance in the face-to-face environment (Xu et al., 2016). We proposed that this argument can be transferred to a blended learning context. However, this does not mean a causality in the line of argument even through it seems reasonable. Therefore, we proposed the following hypotheses:

H5. SRL has an indirect effect on academic performance via perceptions of teachers' credibility.

H5a. SRL has an indirect effect on academic performance via competence.

H5b. SRL has an indirect effect on academic performance via trustworthiness.

H5c. SRL has an indirect effect on academic performance via caring.

\section{Methods}

\section{Participants and procedures}

A total of 467 undergraduates who had completed blended courses in the preceding 3 years took part in an online survey. After deleting incomplete responses, the final sample consisted of 449 (96\%) complete responses; that is, 211 females (47\%) and 238 males (53\%), of whom 86 were in 4th year (19.1\%), 174 in 3rd year (38.8\%), 189 in 2nd year (42.1\%). Their majors varied and consisted of the following disciplines: natural science $(32.7 \%)$, social science $(29.2 \%)$, humanities and the arts $(12.9 \%)$ and engineering $(25.2 \%)$.

This study was conducted at a public university located in the western part of China between November 1 and December 30, 2018, following approval by the university science and technology ethics committee. The university has offered blended learning courses for on-campus bachelor students for nearly 15 years. Most of the courses are optional and run for one semester, about 20 weeks. Teachers use a combination of face-to-face teaching and online teaching. They provide learning resources in Chaoxing, a popular online learning platform in China, for students to learn, assign homework and tests and answer questions online with the help of a teaching assistant. Face-to-face teaching takes place from 3 to 10 weeks, and the rest of the weeks comprise online teaching. There are three classes per week, with each one lasting for 45 minutes. During the face-to-face sessions, the teacher mainly introduces the content and requirements of the course, explains the learning points and difficulties and answers students' questions.

The survey was implemented as follows: First, approval for the present study was obtained from several blended course teachers. Second, the teachers informed the students of the aims of the study, the length of the surveys, the information that would be collected and how the data would be collected, stored and accessed without any personal information being revealed in the report. Finally, the participants were asked to complete a questionnaire survey on the website of Sojump, a popular site in China for online surveys. Each participant received five Chinese yuan for completing the questionnaire. 


\section{Instruments}

$S R L$

SRL was measured using items adapted from the scales used by Kizilcec et al. (2017), Pintrich et al. (1993), Y. Zhu et al. (2016) and Z. Zhu et al. (2005). They were modified slightly to fit into the blended learning context and consisted of five subscales: (a) goal orientation (three items; example question "I set my personal academic performance goals in blended learning"), (b) self-efficacy (three items; example question "I believe that I can achieve good result in this blended course."), (c) cognitive strategy (six items; example question "I think of alternative ways to solve a problem and choose the best one."), (d) metacognitive (three items; "I ask myself questions to make sure I understand the material I have been studying in this blended course") and (e) self-management (six items; example question "Even when the blended course materials are boring, I insist on learning until I finish."). Items for each subscale were measured on a 5-point Likert scale with 1 representing almost never true and 5 representing almost always true. High scores on subscales showed higher levels of self-regulated strategy use.

\section{Teacher credibility}

Students' perceptions of teacher credibility were measured using the Teacher Credibility Scale developed by McCroskey and Teven (1999), which consisted of three six-item subscales: competence (example question "My instructor is intelligent."), trustworthiness (example question "My instructor is honest.") and caring (example question "My instructor has my interests at heart."). Students were asked to rate their teachers' credibility based on these items using 7-point Likert scale with 1 representing strongly disagree and 7 representing strongly agree. High scores on the subscales showed higher levels of credibility.

\section{ICT literacy}

Students' ICT literacy was measured by their test scores in the course University Computer Foundation, which is a compulsory course for all registered students at the university. This course is an introductory course to computers and information technology. It includes computer and ICT literacy, with the main emphasis on competency with software through hands-on practice. Topics include Introduction to Microcomputer Operation, Windows, Word Processing, Spreadsheets, Data Management, Internet and Email. At the end of the course, students took both a practical test and a paper and pencil test. Each test accounted for $50 \%$ of the final score ranging from 0 to 100 . The students self-reported their test scores of the course as the answer to the last question of the survey.

\section{Academic performance}

At this university, students' academic performance in blended learning courses is typically assessed using two measures. First, students are required to complete several online assignments, such as quizzes, which are automatically graded after students' attempts. Second, students take a paper and pencil test at the end of the course, which is graded by the teacher. The students' academic performance on a scale of $0-100$ is computed using an aggregate percentage score recorded for their assignments and the paper test. The official achievements record can be shown on the learning management system of the university with academic performance combined with a standard score. The students were asked to report their standard score level on their most recent blended learning course using a 1-6 scale, where:

- $1=$ scores $<-2$

- $2=$ scores $<-1$ or $\geq-2$

- $3=$ scores $<0$ or $\geq-1$

- $4=$ scores $<1$ or $\geq 0$

- $5=$ scores $<2$ or $\geq 1$

- $6=$ scores $\geq 2$.

\section{Data analysis}

Descriptive statistics for all variables and Pearson's correlations between SRL, perceptions of teachers' credibility, ICT literacy and academic performance were computed. A path analysis was conducted to test the proposed model by using the Lavaan package in $\mathrm{R}$ 3.4.4. At the local level, the statistical significance of each link in the original model was assessed with $p$ values. In addition, at the global level, the goodnessof-fit tests was conducted, as shown by a non-significant $\mathrm{X}^{2}$ goodness-of-fit statistic, $\mathrm{X}^{2} / d f$ ratios of less 
than 5, root mean square error of approximation (RMSEA) less than .05 and comparative fit index (CFI) greater than .95 (Kline, 2011). The initial model (Figure 1) was revised based on modification indices and theoretical reasoning to obtain the final model.

\section{Results}

In this study, the measurement model of SRL was examined by convergent validity, internal consistency reliability and discriminant validity. Convergent validity is assessed with factor loadings, composite reliability (CR) and average variance extracted (AVE) (Fornell \& Larcker, 1981). As shown in Table 1, all factor loadings ranged from 0.76 to 0.95 , exceeding the threshold value of 0.5 ; the $\mathrm{CR}$ ranged from 0.82 to 0.96 , exceeding the threshold value of 0.7 ; and the AVE ranged from 0.61 to 0.83 , exceeding the threshold value of 0.5 (Bagozzi \& Yi, 1989). The Cronbach's alpha value exceeded the cut-off value of 0.7 , which indicates that the internal consistency of the instrument was acceptable.

Table 1

Coefficients for the measurement model of SRL

\begin{tabular}{lcccc}
\hline Construct & Loadings & AVE & CR & Cronbach's alpha \\
\hline Goal orientation (GO) & 0.82 & 0.63 & 0.83 & 0.82 \\
GO1 & 0.88 & & & \\
GO2 & 0.76 & & & \\
GO3 & & 0.71 & 0.88 & 0.86 \\
Self-efficacy (SE) & 0.90 & & & \\
SE1 & 0.94 & & & 0.91 \\
SE2 & 0.81 & & & \\
SE3 & & 0.61 & 0.90 & \\
Cognitive strategy (CS) & 0.79 & & & \\
CS1 & 0.78 & & & \\
CS2 & 0.84 & & & \\
CS3 & 0.83 & & & \\
CS4 & 0.80 & & & \\
CS5 & 0.82 & & 0.81 \\
CS6 & & 0.62 & 0.82 & \\
Metacognitive (M) & 0.89 & & & \\
M1 & 0.87 & & & \\
M2 & 0.80 & & & \\
M3 & & 0.83 & 0.96 & \\
Self-management (SM) & 0.91 & & & \\
SM1 & 0.93 & & & \\
SM2 & 0.95 & & & \\
SM3 & 0.94 & & & \\
SM4 & 0.90 & & \\
SM5 & 0.91 & & & \\
SM6 & & & & \\
\hline
\end{tabular}

Note. $N=449$; AVE: average variance extracted; CR: composite reliability.

Table 2 shows that the discriminant validity was satisfactory because the square root of AVE of the five constructs exceeded the threshold value of 0.5 and was larger than the correlation values between each construct (Fornell \& Larcker, 1981). Accordingly, the measurement model of SRL was acceptable. 
Table 2

The correlations of each construct

\begin{tabular}{llllll}
\hline Construct & Goal orientation & Self-efficacy & Cognitive strategy & Metacognitive & Self-management \\
\hline GO & 0.79 & & & & \\
SE & 0.40 & 0.84 & & & \\
CS & 0.67 & 0.53 & 0.78 & 0.79 & \\
M & 0.41 & 0.33 & 0.34 & 0.37 & 0.91 \\
SM & 0.59 & 0.55 & 0.61 & & \\
\hline
\end{tabular}

Note. GO: goal orientation; SE: self-efficacy; CS: cognitive strategy; M: metacognitive; SM: selfmanagement.

In addition, all three dimensions of teacher credibility achieved acceptable estimates of internal reliability $\left(\alpha_{\text {competence }}=.82, \alpha_{\text {trustworthiness }}=.85, \alpha_{\text {caring }}=.83\right)$.

\section{Descriptive statistics}

As summarised in Table 3, the descriptive statistics for the three dimensions of teacher credibility were competence $(M=21.52, S D=6.81)$, trustworthiness $(M=20.69, S D=6.72)$, caring $(M=18.95, S D=$ 7.00). The mean for caring was the lowest of the three dimensions. Both SRL $(M=60.69, S D=14.22)$ and ICT literacy $(M=74.55, S D=11.26)$ had a mean score higher than their midpoint scores. The mean score of academic performance was low $(M=2.86, S D=0.95)$. In order to check the multivariate normality, the skewness and kurtosis of all variables were examined. The absolute values of skewness ranged from .04 to .42 and the absolute values of kurtosis ranged from .27 to .70. As values were not above a univariate skewness of 2.0 and a univariate of kurtosis of 7.0, multivariate normality was assumed (Curran et al., 1996).

The correlations between academic performance and SRL, competence, trustworthiness and caring were all significant except ICT literacy and academic performance. SRL had the highest positive correlation $(r$ $=0.435)$ and competence the lowest positive correlation $(r=0.302)$ with academic performance. Meanwhile, there were significant positive correlations between SRL and competence, trustworthiness and caring.

Table 3

Descriptive statistics and study variable correlations

\begin{tabular}{lllllllllll}
\hline Variable & $M$ & $S D$ & Skewness & Kurtosis & 1 & 2 & 3 & 4 & 5 & 6 \\
\hline 1. AP & 2.86 & .95 & 0.28 & 0.70 & 1 & & & & & \\
2. SRL & 60.69 & 14.22 & -.04 & -.55 & $.435^{* *}$ & 1 & & & & \\
3. ICTL & 74.55 & 11.26 & -.16 & -.67 & .008 & $.300^{* *}$ & 1 & & & \\
4. Competence & 21.52 & 6.81 & .42 & -.27 & $.302^{* *}$ & $.140^{* *}$ & -.015 & 1 & & \\
5.Trustworthiness & 20.69 & 6.72 & .35 & -.29 & $.369^{* *}$ & $.150^{* *}$ & -.003 & $.773^{* *}$ & 1 & \\
6. Caring & 18.95 & 7.00 & .23 & -.35 & $.426^{* *}$ & $.145^{* *}$ & -.003 & $.392^{* *}$ & $.378^{* *}$ & 1 \\
\hline
\end{tabular}

Note. $N=449$; AP: academic performance; ICTL: ICT literacy.

$* p<.05, * * p<.01$.

\section{Path analysis}

Direct effects between SRL, teacher credibility and academic performance

The initial model tested is shown in Figure 1. All variables were entered into the analysis and the chi-square test of the initial model was significant, $\mathrm{X}^{2}=487.391, \mathrm{X}^{2} / d f=69.627, p<.001$, RMSEA $=.391, \mathrm{CFI}=$ .354. Thus, the model could be improved. Non-significant pathways were dropped to produce a more parsimonious and descriptive model. In particular, the links from SRL to competence and competence to academic performance were removed. Further, as suggested by $\mathrm{R}$ modification indices and the positive correlation between caring and trustworthiness, a direct link between the two was added.

The path analysis was re-implemented, and the second model was significant with adequate model fit indices $\left(\mathrm{X}^{2}=9.287, \mathrm{X}^{2} / d f=3.096, p<.05, \mathrm{RMSEA}=.068, \mathrm{CFI}=.981\right)$. The value of RMSEA was between 0.05 and 0.08, which indicated a reasonable error of approximation (Browne \& Cudeck, 1992). Figure 2 
depicts the final model showing significant pathways and standardised regression coefficients for the relationships between ICT literacy, SRL, trustworthiness and caring and academic performance.

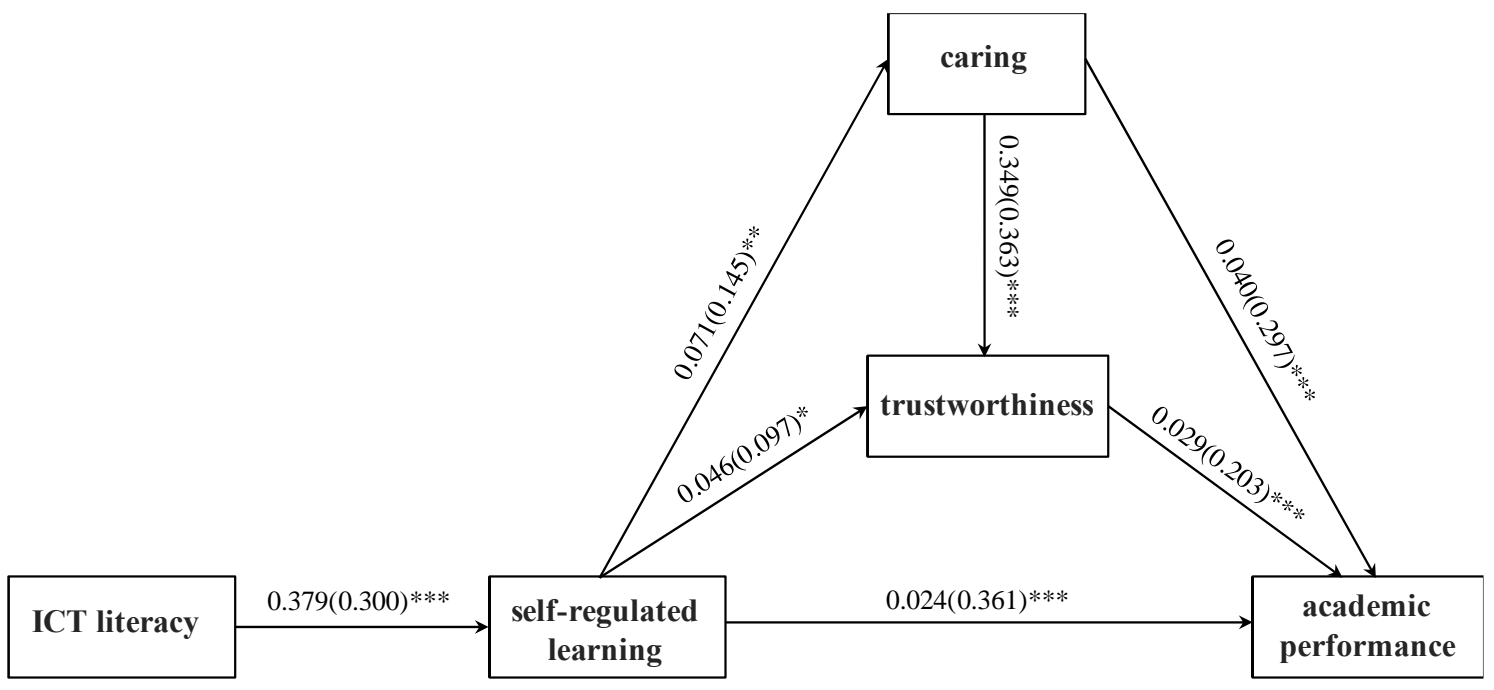

Figure 2. The final model

Note. Standardised coefficient in parentheses.

$* p<.05, * * p<.01, * * * p<.001$

As shown in Table 4, SRL positively predicted caring $(B=.071, p<.01)$, trustworthiness $(B=.046, p<$ $.05)$ and academic performance $(B=.024, p<.001)$. In addition, both caring $(B=.040, p<.001)$ and trustworthiness $(B=.029, p<.001)$ significantly related academic performance. In addition, caring positively predicted trustworthiness $(B=.349, p<.001)$ as well as ICT literacy predicted SRL $(B=0.379$, $p<.001)$.

Table 4

Path analysis results

\begin{tabular}{lllll}
\hline Path & $B$ & $S E$ & $\beta$ & $t$ \\
\hline Caring $\rightarrow$ AP & 0.040 & 0.006 & 0.297 & $7.236^{* * * *}$ \\
Trustworthiness $\rightarrow$ AP & 0.029 & 0.006 & 0.203 & $4.953^{* * *}$ \\
SRL $\rightarrow$ AP & 0.024 & 0.003 & 0.361 & $9.408^{* * *}$ \\
SRL $\rightarrow$ caring & 0.071 & 0.023 & 0.145 & $3.110^{* *}$ \\
SRL $\rightarrow$ trustworthiness & 0.046 & 0.021 & 0.097 & $2.214^{*}$ \\
Caring $\rightarrow$ trustworthiness & 0.349 & 0.042 & 0.363 & $8.272^{* * *}$ \\
ICT literacy $\rightarrow$ SRL & 0.379 & 0.057 & 0.300 & $6.658^{* * *}$ \\
\hline
\end{tabular}

Note. $N=449$; AP: academic performance.

$* p<.05, * * p<.01, * * * p<.001$

Indirect effect of SRL on academic performance

The mediating effects of caring and trustworthiness were tested by analysing the indirect effect of SRL on academic performance. In the path model, SRL had both a direct effect and an indirect effect on academic performance.

Table 5 shows that the indirect effects of SRL on academic performance mediated by both caring $(B=.003$, $p<.01)$ and trustworthiness $(B=.001, p<.05)$; both were significant. Furthermore, SRL had a direct effect $(B=.024, p<.001)$ and an indirect effect $(B=.004, p<.001)$ on academic performance, which summed to a total effect size of .028 . The results indicated that both caring and trustworthiness mediated the impact of SRL on academic performance. 
Table 5

Indirect effect mediated through caring and trustworthiness

\begin{tabular}{ll}
\hline Effect & $B$ \\
\hline Indirect effect mediated through caring & $0.003^{* *}$ \\
Indirect effect mediated through trustworthiness & $0.001^{*}$ \\
Total indirect effect & $0.004^{* * *}$ \\
Direct effect & $0.024^{* * *}$ \\
\hline
\end{tabular}

$* p<.05, * * p<.01, * * * p<.001$

\section{Justification of the hypotheses}

An overview of the results of the hypothesised relationship after path analysis is presented in Table 6 .

Table 6

Hypotheses testing results

\begin{tabular}{ll}
\hline Hypotheses & Results \\
\hline H1. ICT literacy positively correlates with SRL. & supported \\
H2. SRL positively correlates with academic performance. & supported \\
H3. Teachers' credibility positively correlates with academic performance. & not supported \\
H3a. Competence positively correlates with academic performance. & supported \\
H3b. Trustworthiness positively correlates with academic performance. & supported \\
H3c. Caring positively correlates with academic performance. & \\
H4. SRL positively correlates to perceptions of teachers' credibility. & not supported \\
H4a. SRL positively correlates to competence. & supported \\
H4b. SRL positively correlates to trustworthiness. & supported \\
H4c. SRL positively correlates to caring. & \\
H5. SRL has an indirect effect on academic performance via perceptions of teachers' & \\
credibility. & not supported \\
H5a. SRL has an indirect effect on academic performance via competence. & supported \\
H5b. SRL has an indirect effect on academic performance via trustworthiness. & supported \\
H5c. SRL has an indirect effect on academic performance via caring. &
\end{tabular}

\section{Discussion}

The goals of this study were to investigate the relationships between students' SRL, their perceptions of their teachers' credibility, their ICT literacy and their academic performance simultaneously and the mediating effect of perceptions of teachers' credibility on this relationship in blended learning settings.

Results of the study showed that SRL positively predicted academic performance, a finding that is consistent with prior research (Barnark-Brak et al., 2010; Pintrich, 2004; Y. Zhu et al., 2016). In addition, SRL was positively related to perceptions of teacher credibility of caring and trustworthiness but not competence. One possible explanation is that SRL has positive impacts on teacher-learner interactions, which helps to build trusting relationships between teacher and students (Yen et al., 2005). When students trust their teacher, they know that the teacher cares about them, treats them as learners and individuals and has their best academic and social interests at heart. Another explanation is that students with better selfregulated strategies undertook the learning task more independently and asked for less help from the teachers, so that they were less aware of the teachers' competence in blended learning.

Previous studies have shown that teacher credibility positively related to students' academic performance (Gray et al., 2011; McCroskey \& Teven, 1999). Findings from the current study further revealed relationships between subscales of perceptions of teacher credibility and academic performance: caring and trustworthiness were significantly related to academic performance, while competence was not. These findings align with those of Teven and McCroskey (1997), who found that students who identify their teachers as more caring also have a more positive attitude towards the courses and report that they have learned more in the courses. Finn et al. (2009) also have shown that teacher credibility plays a meaningful role in improving students' learning outcomes, while also contributing caring to the teacher credibility 
construct. Dobransky and Frymier (2004) found that students who perceived their teachers as trusting reported greater learning performance.

Possible explanations for these results are as follows. Blended learning combines face-to-face classroom practices with computer-mediated activities. Students have less face-to-face communications with teachers than in traditional teaching settings and, as a result, may feel lonely without enough social support from teachers and peers. Teachers' caring thus takes on a greater role to help build a good interpersonal atmosphere, in which students may feel closer to their teachers and inclined to listen to, learn from and identify with the ones they like. Students come to trust their teacher and value what they say, seeing it as something worth learning because the teacher deem it worth knowing; and it is probable therefore that the student will make more effort to learn the teacher's course materials, thereby improving their learning outcomes (B. Zhang \& Jiang, 2009).

Consistent with prior research (e.g., Teven, 2007), this study found that caring positively predicted trustworthiness. Teven and McCroskey (1997) reported that the correlation between caring and trustworthiness is the highest one among all of the correlations between caring, trustworthiness and competence. This result may partly be explained by the fact that the teacher has to care about students as the starting point for building their trustworthiness in the school setting.

With regards to teacher credibility, the results revealed that both caring and trustworthiness mediated the impact of SRL on academic performance. This suggests that students who are self-regulated learners tend to perceive teachers' caring and trust teachers and achieve better academic performance.

In terms of the relationship between ICT literacy and SRL, ICT literacy was found to predict SRL. This result aligns with findings reported in previous studies. For example, Muthupoltotage and Gardner (2018) found that ICT literacy components affect some SRL subprocesses and obtained evidence for reciprocal relationships. Similarly, Firat (2016) also reported that improving students' ICT literacy and technology use can support growth in students' self-regulation. Thus, if learners possess higher ICT literacy, their selfregulation will increase.

\section{Implications}

The findings of this study provide the following implications for the design of effective blended learning. First, SRL is particularly important because it has positive effects on both the perception of teacher credibility as well as academic performance. Therefore, teachers should consider enacting a few strategies to help facilitate students' SRL. For example, teachers can provide support to assist learners to self-regulate their own learning effectively, rather than simply giving then direct instruction about predefined strategies (Butler, 1998). At the same time, teachers can allow their students to choose academic tasks, work in groups and integrate face-to-face interaction with online discussion in blended learning environment. When students are provided with the freedom and responsibility to plan and organise their learning tasks and tools, they can be more self-motivated to develop their self-regulation skills (McLoughlin \& Lee, 2010). Furthermore, teachers can make comments on students' academic work during face-to-face time and provide constructive suggestions to encourage them to evaluate and reflect on their learning after completing the tasks. Students can improve their self-regulation skills by examining their own work, discussing work with teachers and peers and finding out better solutions (Stoeger \& Ziegler, 2008; Y. Zhu et al., 2016).

Second, teachers' caring and trustworthiness appear to be more important than their competence in terms of helping to improve students' academic performance. In recent years, it is popularly assumed that research and teaching are inextricably linked so much so that only productive researchers are seen as competent at teaching. Research performance is the main and sometimes the only criterion for teachers' promotion at universities in China and throughout the world (Y. Yang et al., 2011). Teachers thus tend to spend most of their time on research and less time on teaching. However, findings from this study suggest that teachers should attach more importance to caring about their students and enhancing their trustworthiness to help improve students' academic performance. In blended learning, teachers can express care towards their students by communicating respect, behaving sensitively, and remaining warm and engaged to improve individual relationships as well as affect the broader climate and gain the students' trust (Meyers, 2009). 
Third, findings showed that students' ICT literacy is positively related to their SRL. Hence, teachers can help facilitate students' SRL by improving their ICT literacy. Teachers can assign online learning tasks for students to complete using learning technologies and topics for them to discuss online via WeChat, Facebook, or other social software. When students engage with online learning and communication, they can gradually improve their ICT literacy.

\section{Conclusion}

The present study found that students' SRL positively predicted their perceptions of teacher caring and trustworthiness as well as their academic performance. It further revealed that the relationship between two subscales of teacher credibility, caring and trustworthiness, significantly predicted academic performance. In addition, perceptions of teacher caring positively predicted teacher trustworthiness; ICT literacy also predicted SRL. More importantly, the results indicated that both teacher caring and trustworthiness mediated the impact of SRL on academic performance.

\section{Limitations}

The study has several limitations. First, the cross-sectional and correlational nature of the data does not allow for causal inferences between SRL, perceptions of teachers' credibility, ICT literacy and academic performance. Hence, analytical and longitudinal research should be conducted in future studies. Second, students were requested to self-report their ICT literacy as well as their perceptions of teachers, which may have been influenced by social desirability even in anonymous questionnaires. Future studies could examine scores from standardised test to better measure ICT literacy level. Third, the participants of the present study were undergraduate students enrolled in blended learning courses at a public university from the western part of China and care should be taken in generalising the results to other populations. Future studies should examine the extent to which the current findings hold true for other universities in other countries.

\section{Acknowledgements}

This work was supported by the Humanities and Social Sciences of Ministry of Education Plan foundation [grant number 19XJA880011]; Higher Education Teaching Reform Project of Chongqing [grant number 202051]; The Key Educational Project of the National Social Science Foundation of China [grant number ACA190006].

\section{References}

Akkoyunlu, B., \& Yilmaz-Soylu, M. (2008). A study of student's perceptions in a blended learning environment based on different learning styles. Educational Technology \& Society, 11(1), 183-193. https://doi.org/10.1016/j.iheduc.2007.12.006

Awang, T. S., \& Zakaria, E. (2013). Enhancing students' understanding in integral calculus through the integration of Maple in learning. Procedia-Social and Behavioral Sciences, 102, 204-211. https://doi.org/10.1016/j.sbspro.2013.10.734

Bagozzi, R. P., \& Yi, Y. (1989). On the evaluation of structural equation models. Journal of Academy Marketing Science, 16, 74-94. https://doi.org/10.1007/BF02723327

Bandura, A. (1977). Self-efficacy: Toward a unifying theory of behavioral change. Psychological Review, 84, 191-215. https://doi.org/10.1037/0033-295X.84.2.191

Bandura, A. (1986). Social foundations of thought and action: A social cognitive theory. Prentice-Hall.

Bandura, A. (1993). Perceived self-efficacy in cognitive development and functioning. Educational Psychologist, 28(2), 117-148. https://doi.org/10.1207/s15326985ep2802_3

Banfield, S. R., Richmond, V. P., \& McCroskey, J. C. (2006). The effect of teacher misbehaviors on teacher credibility and affect for the teacher. Communication Education, 55(1), 63-72. https://doi.org/10.1080/03634520500343400

Barnard, L., Lan, W. Y., To, Y. M., Paton, V. O., \& Lai, S. L. (2009). Measuring self-regulation in online and blended learning environments. Internet and Higher Education, 12(1), 1-6.

https://doi.org/10.1016/j.iheduc.2008.10.005 
Barnark-Brak, L., Lan, W., \& Paton, V. (2010). Profiles in self-regulated learning in the online learning environment. The International Review of Research in Open and Distance Learning, 11(1), 62-80. https://doi.org/10.19173/irrodl.v11i1.769

Bawden, D. (2008). Origins and concepts of digital literacy. In C. Lankshear \& M. Knobel (Eds.), Digital literacies: Concepts, policies and practices (pp. 17-32). Peter Lang.

Boekaerts, M., \& Corno, L. (2005). Self-regulation in the classroom: A perspective on assessment and intervention. Applied Psychology, 54(2), 199-231. https://doi.org/10.1111/j.1464-0597.2005. 00205.x

Broadbent, J., \& Poon, W. L. (2015). Self-regulated learning strategies \& academic achievement in online higher education learning environments: A systematic review. The Internet and Higher Education, 27, 1-13. https://doi.org/10.1016/j.iheduc.2015.04.007

Browne, M. W., \& Cudeck, R. (1992). Alternative ways of assessing model fit. Sociological Methods \& Research, 21(2), 230-258. https://doi.org/10.1177/0049124192021002005

Bruner, J. S. (2009). The process of education. Harvard University Press. https://doi.org/10.2307/j.ctvk12qst

Butler, D. L. (1998). The strategic content learning approach to promoting self-regulated learning: A report of three studies. Journal of Educational Psychology, 90(4), 682-697. https://doi.org/10.1037/0022-0663.90.4.682

Butler, D. L., \& Winne, P. H. (1995). Feedback and self-regulated learning: A theoretical synthesis. Review of Educational Research, 65(3), 245-281. https://doi.org/10.3102/00346543065003245

Cooper, L. (1932). The rhetoric of Aristotle. Appleton-Century-Crofts.

Curran, P. J., West, S. G., \& Finch, J. F. (1996). The robustness of test statistics to nonnormality and specification error in confirmatory factor analysis. Psychological Methods, 1(1), 16-29. https://doi.org/10.1037/1082-989X.1.1.16

Dobransky, N. D., \& Frymier, A. B. (2004). Developing teacher-student relationships through out of class communication. Communication Quarterly, 52(3), 211-223. https://doi.org/10.1080/01463370409370193

Efklides, A. (2011). Interactions of metacognition with motivation and affect in self-regulated learning: The MASRL model. Educational Psychologist, 46(1), 6-25. https://doi.org/10.1080/00461520.2011.538645

Evertson, C. M., \& Weinstein C. S. (2006). Handbook of classroom management: Research, practice, and contemporary issues. Erlbaum.

Finn, A. N., Schrodt, P., Witt, P. L., Elledge, N., Jernberg, K. A., \& Larson, L. M. (2009). A meta analytical review of teacher credibility and its associations with teacher behaviors and student outcomes. Communication Education, 58(4), 516-537. https://doi.org/10.1080/03634520903131154

Firat, M. (2016). Measuring the e-learning autonomy of distance education students. Open Praxis, $8(3)$, 191-201. https://doi.org/10.5944/openpraxis.8.3.310

Fornell, C., \& Larcker, D. F. (1981). Evaluating structural equation models with unobservable variables and measurement error. Journal of Marketing Research, 18(1), 39-50. https://doi.org/10.2307/3151312

Fraillon, J., Schulz, W., \& Ainley, J. (2013). International computer and information literacy study: Assessment framework. International Association for the Evaluation of Educational Achievement. https://www.iea.nl/publications/assessment-framework/international-computer-and-informationliteracy-study-2013

Garrison, D. R., \& Kanuka, H. (2004). Blended learning: Uncovering its transformative potential in higher education. The Internet and Higher Education, 7(2), 95-105. https://doi.org/10.1016/j.iheduc.2004.02.001

Godbey, S. (2018). Testing future teachers: A quantitative exploration of factors impacting the information literacy of teacher education students. College and Research Libraries, 79(5), 611-623. https://doi.org/10.5860/crl.79.5.611

Gray, D. L., Anderman, E. M., \& O’Connell, A. A. (2011). Associations of teacher credibility and teacher affinity with learning outcomes in health classrooms. Social Psychology of Education, 14(2), 185208. https://doi.org/10.1007/s11218-010-9143-X

Greene, J. A., Seung, B. Y., \& Copeland, D. Z. (2014). Measuring critical components of digital literacy and their relationships with learning. Computers \& Education, 76, 55-69.

https://doi.org/10.1016/j.compedu.2014.03.008 
Hadwin, A. F., Järvelä, S., \& Miller, M. (2011). Self-regulated, co-regulated, and socially shared regulation of learning. In B. J. Zimmerman \& D. H. Schunk (Eds.), Handbook of self-regulation of learning and performance (pp. 65-84). Routledge. https://doi.org/10.4324/9780203839010.ch5

Hutchens, J. S., \& Hayes, T. (2014). In your Facebook: Examining Facebook usage as misbehavior on perceived teacher credibility. Education Information Technology, 19, 5-20. https://doi.org/10.1007/s10639-012-9201-4

Ibrahim, M. M., \& Nat, M. (2019). Blended learning motivation model for instructors in higher education institutions. International Journal of Educational Technology in Higher Education, 16(1), 12. https://doi.org/10.1186/s41239-019-0145-2

Jaderstrom, S. (1995). Technology's impact on computer and business curricula. In N. J. Groneman \& K. C. Kaser (Eds.), Technology in the classroom (pp. 1-9). National Business Education Association.

Jeffrey, L. M., Milne, J., \& Suddaby, G. (2014). Blended learning: How teachers balance the blend of online and classroom components. Journal of Information Technology Education Research, 13, 121140. https://doi.org/10.28945/1968

Jia, J., Chen, Y., Ding, Z., \& Ruan, M. (2012). Effects of a vocabulary acquisition and assessment system on students' performance in a blended learning class for English subject. Computers \& Education, 58(1), 63-76. https://doi.org/10.1016/j.compedu.2011.08.002

Joo, Y. J., Joung, S., \& Kim, J. (2014). Structural relationships among self-regulated learning, learning flow, satisfaction, and learning persistence in cyber universities. Interactive Learning Environments, 22(6), 752-770. https://doi.org/10.1080/10494820.2012.745421

Kiliç-Çakmak, E. (2010). Learning strategies and motivational factors predicting information literacy self-efficacy of e-learners. Australasian Journal of Educational Technology, 26(2), 192-208. https://doi.org/10.14742/ajet.1090

Kizilcec, R. F., Pérez-Sanagustín, M., \& Maldonado, J. J. (2017). Self-regulated learning strategies predict learner behavior and goal attainment in Massive Open Online Courses. Computers \& Education, 104, 18-33. https://doi.org/10.1016/j.compedu.2016.10.001

Kline, B. (2011). Principles and practice of structural equation modeling (3rd ed.). The Guilford Press.

Kuo, Y. C., Walker, A. E., Schroder, K. E., \& Belland, B. R. (2014). Interaction, Internet self-efficacy, and self-regulated learning as predictors of student satisfaction in online education courses. The Internet and Higher Education, 20, 35-50. https://doi.org/10.1016/j.iheduc.2013.10.001

Ledbetter, A. M., \& Finn, A. N. (2016). Why do students use mobile technology for social purposes during class? Modeling teacher credibility, learner empowerment, and online communication attitude as predictors. Communication Education, 65(1), 1-23. https://doi.org/10.1080/03634523.2015.1064145

Lennon, M., Kirsch, I., Von Davier, M., Wagner, M., \& Yamamoto, K. (2003). Feasibility study for the PISA ICT literacy assessment: Report to network A. Organization for Economic Co-operation and Development. http://www.oecd.org/education/school/programmeforinternationalstudentassessmentpisa/33699866.pd $\underline{f}$

Mazer, J. P., Murphy, R. E., \& Simonds, C. J. (2009). The effects of teacher self-disclosure via Facebook on teacher credibility. Learning, Media and Technology, 34(2), 175-183.

https://doi.org/10.1080/17439880902923655

McCroskey, J. C. (1992). An introduction to communication in the classroom. Burgess International.

McCroskey, J. C. (1998). An introduction to communication in the classroom (2nd ed.). Tapestry Press.

McCroskey, J. C., \& Teven, J. J. (1999). Goodwill: A reexamination of the construct and its measurement. Communication Monographs, 66(1), 90-103. https://doi.org/10.1080/03637759909376464

McCroskey, J. C., \& Young, T. J. (1981). Ethos and credibility: The construct and its measurement after three decades. Central States Speech Journal, 32, 24-34. https://doi.org/10.1080/10510978109368075

McLoughlin, C., \& Lee, M. J. W. (2010). Personalised and self-regulated learning in the Web 2.0 era: International exemplars of innovative pedagogy using social software. Australasian Journal of Educational Technology, 26(1), 28-43. https://doi.org/10.14742/ajet.1100

Meyers, S. A. (2009). Do your students care whether you care about them? College Teaching, 57(4), 205210. https://doi.org/10.1080/87567550903218620 
Moskal, P., Dziuban, C., \& Hartman, J. (2013). Blended learning: A dangerous idea? The Internet and Higher Education, 18, 15-23. https://doi.org/10.1016/j.iheduc.2012.12.001

Muthupoltotage, U. P., \& Gardner, L. (2018). Analyzing the relationships between digital literacy and self-regulated learning of undergraduates - A preliminary investigation. In N. Paspallis, M. Raspopoulos, C. Barry, M. Lang, H. Linger, \& C. Schneider (Eds.), Lecture notes in information systems and organisation: vol. 26. Advances in information systems development (pp. 1-16). Springer. https://doi.org/10.1007/978-3-319-74817-7 1

Özsevgeç, T. (2011). Computer literacy of Turkish preservice teachers in different teacher training programs. Asia Pacific Education Review, 12(1), 13-21. https://doi.org/10.1007/s12564-010-9123-z

Panadero, E. (2017). A review of self-regulated learning: Six models and four directions for research. Frontiers in psychology, 8, 1-28. https://doi.org/10.3389/fpsyg.2017.00422

Panadero, E., \& Alonso-Tapia, J. (2014). ¿Cómo autorregulan nuestros alumnos? Modelo de Zimmerman sobre estrategias de aprendizaje [How do students self-regulate? Review of Zimmerman's cyclical model of self-regulated learning]. Anales De Psicologia, 30(2), 450-462. https://doi.org/10.6018/analesps.30.2.167221

Pintrich, P. R. (2000). The role of goal orientation in self-regulated learning. In M. Boekaerts, P. Pintrich, \& M. Zeidner (Eds.), The handbook of self-regulation: Theory, research, and applications (pp. 451502). Academic Press. https://doi.org/10.1016/B978-012109890-2/50043-3

Pintrich, P. R. (2004). A conceptual framework for assessing motivation and self-regulated learning in college students. Educational Psychology Review, 16(4), 385-407. https://doi.org/10.1007/s10648004-0006-X

Pintrich, P. R., Smith, D. A., García, T., \& McKeachie, W. J. (1993). Reliability and predictive validity of the motivated strategies for learning questionnaire (MSLQ). Educational and Psychological Measurement, 53(3), 801-813. https://doi.org/10.1177/0013164493053003024

Pogue, L. L., \& AhYun, K. (2006). The effect of teacher nonverbal immediacy and credibility on student motivation and affective learning. Communication Education, 55(3), 331-344. https://doi.org/10.1080/03634520600748623

Puustinen, M., \& Pulkkinen, L. (2001). Models of self-regulated learning: A review. Scandinavian Journal of Educational Research, 45(3), 269-286. https://doi.org/10.1080/00313830120074206

Puzziferro, M. (2008). Online technologies self-efficacy and self-regulated learning as predictors of final grade and satisfaction in college-level online courses. American Journal of Distance Education, 22(2), 72-89. https://doi.org/10.1080/08923640802039024

Richmond, V. P., Lane, D. R., \& McCroskey, J. C. (2006). Teacher immediacy and the teacher-student relationship. In T. P. Mottet, V. P. Richmond, \& J. C. McCroskey (Eds.), Handbook of instructional communication: Rhetorical and relational perspectives (pp. 167-193). Pearson.

Rohatgi, A., Scherer, R., \& Hatlevik, O. E. (2016). The role of ICT self-efficacy for students' ICT use and their achievement in a computer and information literacy test. Computers \& Education, 102, 103-116. https://doi.org/10.1016/j.compedu.2016.08.001

Schunk, D. H., \& Zimmerman, B. J. (1994). Self-regulation of learning and performance: Issues and educational applications. Routledge.

Shea, P., \& Bidjerano, T. (2010). Learning presence: Towards a theory of self-efficacy, self-regulation, and the development of a communities of inquiry in online and blended learning environments. Computers \& Education, 55(4), 1721-1731. https://doi.org/10.1016/j.compedu.2010.07.017

Squibb, S. D., \& Mikkelsen, S. (2016). Assessing the value of course-embedded information literacy on student learning and achievement. College \& Research Libraries, 77(2), 164-183. https://doi.org/10.5860/crl.77.2.164

Stoeger, H., \& Ziegler, A. (2008). Evaluation of a classroom based training to improve self-regulation in time management tasks during homework activities with fourth graders. Metacognition Learning, 3(3), 207-230. https://doi.org/10.1007/s11409-008-9027-z

Tang, C. M., \& Chaw, L. Y. (2016). Digital literacy: A prerequisite for effective learning in a blended learning environment? Electronic Journal of E-learning, 14(1), 54-65. https://academicpublishing.org/index.php/ejel/article/view/1743 
Teven, J. J. (2007). Teacher caring and classroom behavior: Relationships with student affect and perceptions of teacher competence and trustworthiness. Communication Quarterly, 55(4), 433-450. https://doi.org/10.1080/01463370701658077

Teven, J. J., \& Hanson, T. L. (2004). The impact of teacher immediacy and perceived caring on teacher competence and trustworthiness. Communication Quarterly, 52(1), 39-53. https://doi.org/10.1080/01463370409370177

Teven, J. J., \& McCroskey, J. C. (1997). The relationship of perceived teacher caring with student learning and teacher evaluation. Communication Education, 46(1), 1-9. https://doi.org/10.1080/03634529709379069

Thweatt, K.S., \& McCroskey, J.C. (1998). The impact of teacher immediacy and misbehaviors on teacher credibility. Communication Education, 47(4), 348-358. https://doi.org/10.1080/03634529809379141

Tormala, Z. L., Briñol, P., \& Petty, R. E. (2006). When credibility attacks: The reverse impact of source credibility on persuasion. Journal of Experimental Social Psychology, 42(5), 684-691. https://doi.org/10.1016/j.jesp.2005.10.005

Vandewalle, D. (1997). Development and validation of a work domain goal orientation instrument. Educational and psychological measurement, 57(6), 995-1015. https://doi.org/10.1177/0013164497057006009

Wang, C. H., Shannon, D. M., \& Ross, M. E. (2013). Students' characteristics, self-regulated learning, technology self-efficacy, and course outcomes in online learning. Distance Education, 34(3), 302323. https://doi.org/10.1080/01587919.2013.835779

Webber, S., \& Johnston, B. (2000). Conceptions of information literacy: New perspectives and implications. Journal of information science, 26(6), 381-397. https://doi.org/10.1177/016555150002600602

Westerman, D., Spence, P. R., \& Van Der Heide, B. (2012). A social network as information: The effect of system generated reports of connectedness on credibility on Twitter. Computers in Human Behavior, 28(1), 199-206. https://doi.org/10.1016/j.chb.2011.09.001

Xu, H., Chen, G., \& Ma, H. (2016). 教师对学生自主学习支持程度与学生化学学习相关性的实证研 究 [An empirical study of the correlation between the support degree of teachers to the students' autonomous learning and the students' chemistry learning]. Curriculum, Teaching Material and Method, 36(2), 100-106. https://doi.org/10.19877/j.cnki.kcjcjf.2016.02.015

Yang, M. S., \& Kim, J. K. (2014). Correlation between digital literacy and self-regulated learning skills of learners in university e-learning environment. Advanced Science and Technology Letters, 71, 80 83. https://doi.org/10.14257/astl.2014.71.19

Yang, Y., Liu, Y., \& Zhou, X. (2011). 高校教学与科研互动: 问题、归因及对策 [Integration of teaching and research in university: problems, attributions and countermeasures]. Educational Research, 23(8), 55-58. http://www.cqvip.com/QK/96925X/201108/38631254.html

Ye, L. R. (2000). The impact of computer literacy on student academic performance in the introductory management information systems course. Academy of Information and Management Sciences Journal, 3(2), 89-98.

Yen, N. L., Bakar, K. A., Roslan, S., Suluan, W., \& Rahman, P. Z. M. A. (2005). Self-regulated learning and its relationship with student-teacher interaction. Pakistan Journal of Psychological Research, 20(1-2), 41-64. http://www.pjprnip.edu.pk/index.php/pjpr/article/view/447

You, J. W., \& Kang, M. (2014). The role of academic emotions in the relationship between perceived academic control and self-regulated learning in online learning. Computers \& Education, 77, 125 133. https://doi.org/10.1016/j.compedu.2014.04.018

Zhang, B., \& Jiang, T. (2009). 初中生师生关系对学业成绩的影响研究 [A correlation analysis of teacher-student relationship and academic achievement in junior high schools]. High Schools Psychological Science, 32(4), 1015 -1017. https://doi.org/10.16719/j.cnki.1671-6981.2009.04.068

Zhang, Q., Zhang, J., \& Castelluccio, A. (2011). A cross-cultural investigation of student resistance in college classrooms: The effects of teacher misbehaviors and credibility. Communication Quarterly, 56(2), 209-227. https://doi.org/10.1080/01463373.2011.597287

Zhang, Y., \& Rong, H. (2013). 教师在远程英语自主学习中的预期角色和实际行为研究 [The research on teachers' expected role and actual behavior during English major students' self-regulated learning online]. China Distance Education, (4), 83-88. https://doi.org/10.13541/j.cnki.chinade.2013.04.002 
Zhu, Y., Au, W., \& Yates, G. (2016). University students' self-control and self-regulated learning in a blended course. The Internet and Higher Education, 30, 54-62. https://doi.org/10.1016/j.iheduc.2016.04.001

Zhu, Z., Wang, J., Zhang, W., \& Ye, Q. (2005). 大学生自主学习量表的编制 [The development of selfregulated learning scale for college students]. Psychological Development and Education, 21(3), 6065.

https://kns.cnki.net $/ \mathrm{kcms} /$ detail $/$ detail.aspx $? \mathrm{dbcode}=\mathrm{CJFD} \&$ filename$=X L F Z 200503012 \& \mathrm{dbname}=\mathrm{CJ}$ FD2005

Zimmerman, B. J. (1989). A social cognitive view of self-regulated academic learning. Journal of Educational Psychology, 81(3), 329-339. https://doi.org/10.1037/0022-0663.81.3.329

Zimmerman, B. J. (2000). Attaining self-regulation: A social cognitive perspective. In M. Boekaerts, P. R. Pintrich, \& M. Zeidner (Eds.), Handbook of self-regulation (pp. 13-39). Academic Press. https://doi.org/10.1016/B978-012109890-2/50031-7

Zimmerman, B. J. (2008). Investigating self-regulation and motivation: Historical background, methodological developments, and future prospects. American Educational Research Journal, 45(1), 166-183. https://doi.org/10.3102/0002831207312909

Zimmerman, B. J., \& Schunk, D. H. (2012). Self-regulated learning and academic achievement: Theory, research, and practice. Springer-Verlag. https://doi.org/10.4324/9781410601032

Zuckerman, G. (1994). A pilot study of a ten-day course in cooperative learning for beginning Russian first graders. Elementary School Journal, 94, 405-520. https://doi.org/10.1086/461775

Corresponding author: Liang Yu, yuliang@swu.edu.cn

Copyright: Articles published in the Australasian Journal of Educational Technology (AJET) are available under Creative Commons Attribution Non-Commercial No Derivatives Licence (CC BY-NC-ND 4.0). Authors retain copyright in their work and grant AJET right of first publication under CC BY-NC-ND 4.0 .

Please cite as: Yu, L., Chen, S., \& Recker, M. (2021). Structural relationships between self-regulated learning, teachers' credibility, information and communications technology literacy and academic performance in blended learning. Australasian Journal of Educational Technology, 37(4), 33-50. https://doi.org/10.14742/ajet.5783 